\title{
THE
}

5-13-2016

\section{Depth Profiles of Persistent Organic Pollutants in the North and Tropical Atlantic Ocean}

Caoxin Sun

Thomas Soltwedel

Eduard Bauerfeind

Dave A. Adelman

Rainer Lohmann

University of Rhode Island, rlohmann@uri.edu

Follow this and additional works at: https://digitalcommons.uri.edu/gsofacpubs

The University of Rhode Island Faculty have made this article openly available.

Please let us know how Open Access to this research benefits you.

This is a pre-publication author manuscript of the final, published article.

Terms of Use

This article is made available under the terms and conditions applicable towards Open Access Policy Articles, as set forth in our Terms of Use.

\section{Citation/Publisher Attribution}

Sun, C., Soltwedel, T., Bauerfeind, E., Adelman, D. A., \& Lohmann, R. (2016). Depth Profiles of Persistent Organic Pollutants in the North and Tropical Atlantic Ocean. Environ. Sci., Technol., 50(12): 6172-6179. Available at: http://dx.doi.org/10.1021/acs.est.5b05891

This Article is brought to you for free and open access by the Graduate School of Oceanography at DigitalCommons@URI. It has been accepted for inclusion in Graduate School of Oceanography Faculty Publications by an authorized administrator of DigitalCommons@URI. For more information, please contact digitalcommons-group@uri.edu. 


\section{Depth profiles of persistent organic pollutants}

\section{2 in the North and Tropical Atlantic Ocean}

3 Caoxin Sun ${ }^{1}$, Thomas Soltwedel ${ }^{2}$, Eduard Bauerfeind, ${ }^{2}$ Dave A. Adelman ${ }^{1}$, Rainer

$$
\operatorname{Lohmann}^{1, *}
$$

$5{ }^{1}$ Graduate School of Oceanography, University of Rhode Island, South Ferry Road, Narragansett, 02882 Rhode Island, United States

$7 \quad{ }^{2}$ Alfred-Wegener-Institut, Helmholtz-Zentrum für Polar- und Meeresforschung, Am Handelshafen 12, 27570 Bremerhaven, Germany 


\section{ABSTRACT}

10 Little is known of the distribution of persistent organic pollutants (POPs) in the deep ocean.

11 Polyethylene passive samplers were used to detect the vertical distribution of truly

12 dissolved POPs at two sites in the Atlantic Ocean. Samplers were deployed at five depths

13 covering $26-2535 \mathrm{~m}$ in the northern Atlantic and Tropical Atlantic, in approximately one

14 year deployments. Samplers of different thickness were used to determine the state of

15 equilibrium POPs reached in the passive samplers. Concentrations of POPs detected in the

16 North Atlantic near the surface (e.g. sum of 14 polychlorinated biphenyls, PCBs: $0.84 \mathrm{pg}$

$17 \mathrm{~L}^{-1}$ ) were similar to previous measurements. At both sites, PCB concentrations showed

18 sub-surface maxima (tropical Atlantic Ocean $-800 \mathrm{~m}$, North Atlantic - $500 \mathrm{~m}$ ). Currents

19 seemed more important in moving POPs to deeper water masses than the biological pump.

20 The ratio of PCB concentrations in near surface waters (excluding PCB-28) between the

21 two sites was inversely correlated with congeners' sub-cooled liquid vapor pressure, in

22 support of the latitudinal fractionation. The results presented here implied a significant

23 amount of HCB is stored in the Atlantic Ocean (4.8-26\% of the global HCB environmental

24 burdens), contrasting traditional beliefs that POPs do not reach the deep ocean. 


\section{INTRODUCTION}

27 Open ocean seawater measurements of persistent organic pollutants (POPs) are scarce

28 due to the difficulties associated with the sampling procedure, contamination and costs of

29 cruises. $^{1}$ There are even less data on POPs in the deep ocean, since most of the

30 measurements of POPs in the open ocean were limited to surface seawater. Little is known

31 of the role played by deep ocean compartments in storing POPs from the surface. ${ }^{2}$ Of the

32 few previous measurements of deep oceanic POPs, two were based on active sampling,

33 targeting polychlorinated biphenyls (PCBs) and polycyclic aromatic hydrocarbons (PAHs)

34 in deep waters in the North Atlantic (near the South-Western edge of the Porcupine Abyssal

35 Plain and around Iceland) ${ }^{3}$, and PCBs in the central Arctic Basins (Nansen, Amundsen,

36 and Makarov). ${ }^{4}$ More recently, concentrations of PCBs, PAHs, hexachlorobenzene (HCB)

37 and dichlorodiphenyldichloroethylene (DDE) were detected using passive sampling at 0.1-

$385 \mathrm{~km}$ depth in the Irminger Sea, the Canary Basin and the Mozambique Channel. ${ }^{2}$ These

39 studies reported the existence of POPs in the deeper ocean and indicated that the deep

40 oceans could be an important compartment for storing POPs.

41 The study by Booij et al. ${ }^{2}$ was the first to use passive sampling (semipermeable

42 membrane devices, SPMDs) to study the POPs vertical distribution in the ocean. Even

43 though active sampling has been traditionally used, it bears the disadvantage of extensive

44 labor and extreme care of controlling blank levels. ${ }^{2}$ Polyethylene sheets (PEs) is one

45 common form of passive sampling devices. It has many advantages including simplicity in

46 its chemical makeup, low cost, easy handling and a high enrichment of POPs. ${ }^{5}$ Passive

47 sampling was recently suggested a useful tool used monitoring POPs in open ocean. ${ }^{6}$ 
48 Unlike active sampling, passive samplers only take up 'truly' dissolved compounds, not

49 those bound to colloids.

50 Under the circumstances that the time to reach equilibrium is not known, the sampling

51 rate $\left(R_{\mathrm{S}}\right)$ can be used to derive the state of equilibrium upon retrieval. One way to calibrate

$52 R_{\mathrm{S}}$ is to use performance reference compounds (PRCs). PRCs are chemicals that are

53 artificially made which share similar properties to target compounds. However, due to the

54 extensive long time of pre-spiking samplers with PRCs, another approach has been

55 suggested by Bartkow et al. ${ }^{7}$ using different thickness to confirm that equilibrium has been

56 reached.

57 In this study, polyethylene passive samplers of different thickness were deployed at two

58 deep ocean sites (eastern Fram Strait and Cape Verde Abyssal Plain) in the Atlantic Ocean

59 to determine vertical distributions of truly dissolved concentrations of several classes of

60 POPs, including PCBs, organochlorine pesticides (OCPs), polybrominated diphenyl ethers

61 (PBDEs) and PAHs. The objectives of this study were to (i) measure a wide range of POPs

62 in vertical profiles at two locations in the North Atlantic; (ii) contrast north-south and

63 surface-to-deep gradients and (iii) improve the knowledge of fate and transport of POPs to

64 the deep ocean.

65

66 


\section{METHODS}

\section{$68 \quad$ Sampling}

$69 \quad$ PE sheet samplers preparation

70 PEs of three thickness were used in the study: 800,1600 and $50 \mu \mathrm{m}$. Polyethylene

71 samplers preparation details are given in Supporting Information. Only 50 $\mu \mathrm{m}$ PEs were

72 pre-spiked with PRCs using the method described by Booij et al. ${ }^{8}$

$74 \quad$ Deep mooring sampling

75 Samplers were strung on stainless steel wires and attached to stainless porous cages.

76 Cages were attached to deep mooring systems and deployed in North Atlantic $\left(79^{\circ} \mathrm{N}, 4^{\circ}\right.$

77 E) and Tropical Atlantic $\left(25^{\circ} \mathrm{N}, 38^{\circ} \mathrm{W}\right)$ (Figure 1). Deployment depths were $213 \mathrm{~m}, 468$

$78 \mathrm{~m}, 1173 \mathrm{~m}, 1736 \mathrm{~m}$ and $2535 \mathrm{~m}$ for the North Atlantic and $26 \mathrm{~m}, 84 \mathrm{~m}, 251 \mathrm{~m}, 800 \mathrm{~m}$ and

$791800 \mathrm{~m}$ for the tropical Atlantic Ocean, respectively. Two sampling sheets were deployed

80 at each depth. Sampling time was around one year for both deployments (North Atlantic:

81 July $21^{\text {st }} 2012 \sim$ July $8^{\text {th }} 2013$; Tropical Atlantic: Sep $14^{\text {th }} 2012 \sim$ Oct $1^{\text {st }} 2013$ ). Current

82 velocities were also measured at different depths by current meters during the entire

83 mooring period. Current velocities were averaged over the deployment time for discussion

84 in this paper. After samples were collected, they were wrapped in clean aluminum foil, 85 shipped back to lab and stored at $-4^{\circ} \mathrm{C}$ until analysis. 


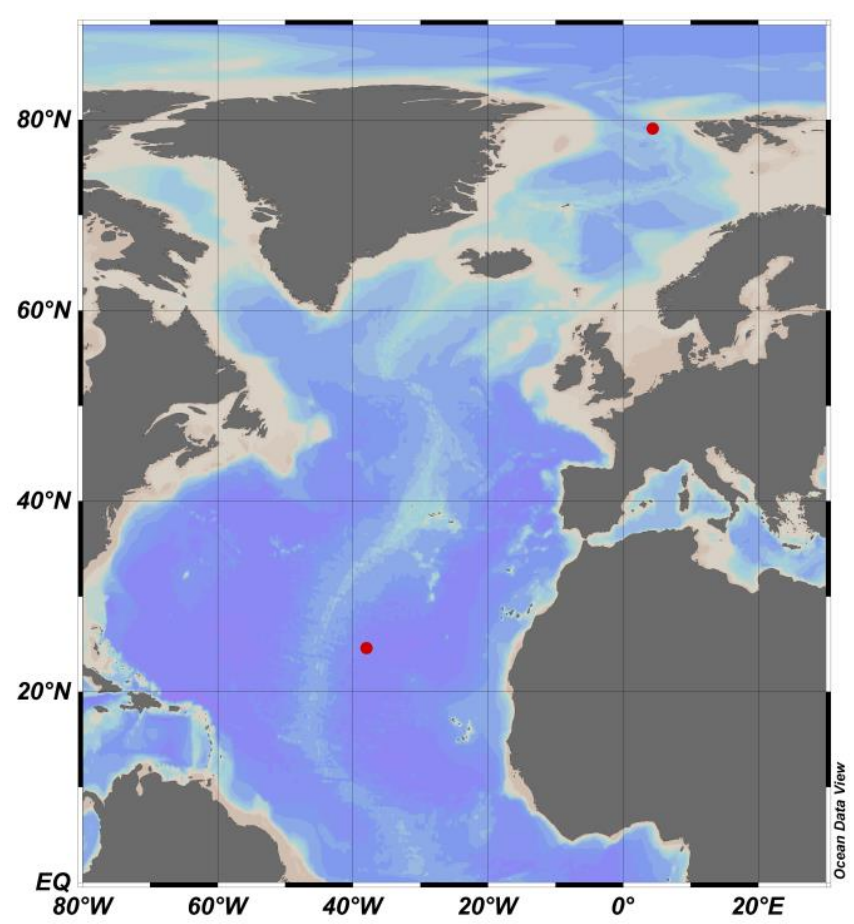

Figure 1. Sampling locations of the deep moorings in 2011-12.

\section{$89 \quad$ Sample analysis}

$90 \quad$ Sample extraction

91 After being wiped clean using Kimwipes, PEs were cut into pieces and extracted in

92 hexane overnight twice with surrogate injected. Extracts were then concentrated into GC-

93 vials and analyzed by GC-MS/ GC-MS-MS. Details on sample extraction and instrumental

94 analysis are given in the Supporting Information.

96 Quality assurance/quality control

97 Matrix spike and lab blanks were performed for each batch of approximately 10 samples.

98 Field blanks were taken during the North Atlantic deployment. All blanks were extracted

99 in the same method as samples. Limits of detection (LOD) were derived from field blanks 
100 and determined by three times the standard deviation of field blank samples. Detailed

101 QA/QC information are in the Supporting Information (detection limits of all the

102 compounds quantified in this study are given in Table S3; recoveries are given in Table

103 S4).

104

105 PE concentration $\left(C_{\mathrm{PE}}\right)$ conversion to environmental concentration

106 Concentration of target compounds in the PEs $\left(C_{\mathrm{PE}}, \mathrm{ng}^{-1}\right)$ were converted to freely

107 dissolved water concentrations $\left(C_{\mathrm{w}}, \mathrm{kg} \mathrm{L}^{-1}\right)$ by equation (1)

$108 \quad C_{\mathrm{w}}=\frac{C_{\mathrm{PE}}}{K_{\mathrm{PEw}}} \times \frac{1}{\% \text { equilibrium }}$

109 where

$110 K$ PEw is the compound specific partitioning coefficient between PE and water $\left(\mathrm{L} \mathrm{kg}^{-1}\right)$

111 whose temperature correction for $K_{\mathrm{PEw}}$ was done using equation (2), and

$112 \%$ equilibrium is the percentage of equilibrium achieved by individual compound in the

113 sampling period which is given by equation (3)

$114 \quad K_{\mathrm{PEw}}(T)=K_{\mathrm{PEw}}(298) \mathrm{e}^{\left(\Delta H_{\mathrm{PEw}} / \mathrm{R}\right)\left\{\frac{1}{298}-\frac{1}{T}\right\}}$

115 where

$116 K_{\mathrm{PEw}}(T)$ and $K_{\mathrm{PEw}}(298)$ are PEw partitioning coefficients at temperature $T(\mathrm{~K})$ and 298

117 K, respectively;

$118 \Delta H_{\mathrm{PEw}}$ is the enthalpy of PEw partitioning $\left(\mathrm{kJ} \mathrm{mol}^{-1}\right)$;

119 and $\mathrm{R}$ is the universal gas constant $\left(8.3143 \mathrm{~J} \mathrm{~mol}^{-1} \mathrm{~K}^{-1}\right)$;

$120 \quad \%$ equilibrium $=1-\mathrm{e}^{\left(\frac{-R_{\mathrm{PEw}} t}{K_{\mathrm{PE}} V_{\mathrm{PE}}}\right)}$ 
$121 \quad$ where

$122 R_{\mathrm{S}}$ is the sampling rate (L/day) for one whole sampling sheet;

$123 t$ is sampling time (days); and

$124 \quad V_{\mathrm{PE}}$ is the volume of the PE (L).

125

126 Estimations of sampling rates

127 Using different thickness

128 Sampling rates were estimated based on the assumption that PEs deployed at the same

129 depth/cage were exposed to the same truly dissolved concentration $\left(C_{\mathrm{w}}\right)$, and that the same

130 sampling rate applied to all compounds. $R_{\mathrm{s}}$ pairs were assumed to be from different

131 combinations of integers from $1 \sim \mathrm{X}$ L/day $(X=100,50,40,3020,10)$. For each

132 combination, \%equilibrium was calculated using equation (6) and the environmental

133 concentration was further determined using equation (1). The aim was to find the exact pair

134 of $R_{\mathrm{S}}$ that minimizes the total of standard deviations of all detected compounds. The total

135 of standard deviations is defined as

$136 \quad \sum_{i=1}^{n} s_{i}$

137 where

$138 \mathrm{n}$ is the number of pairs of data, and

$139 \mathrm{~s}$ is the standard deviation of the derived environmental concentration $\left(x_{\mathrm{j}}\right)$ by the two PEs

140 in the same cage

141

$$
s=\sqrt{\frac{1}{N-1} \sum_{j=1}^{N}\left(x_{j}-\bar{x}\right)^{2}} \quad(N=2)
$$


$143 \quad$ Using PRCs

144 Site specific sampling rates were also calculated via a nonlinear least-squares method

145 adapted from Booij and Smedes. ${ }^{9}$ This method only applies to PEs that were pre-spiked

146 with PRCs, i.e., the $50 \mu \mathrm{m}$ thick ones in the tropical Atlantic $84 \mathrm{~m}$ and $251 \mathrm{~m}$ deployment.

$148 \quad$ Latitudinal Fractionation

149 The ratio of the concentration of each individual compound near the surface layer (231

$150 \mathrm{~m})$ at $79^{\circ} \mathrm{N}$ divided by the surface concentration at $24^{\circ} \mathrm{N}(26 \mathrm{~m})$ was plotted as a function

151 of their subcooled liquid vapor pressure $\left(\mathrm{P}_{\mathrm{L}}\right)$.

153 Estimation of water age using chlorofluorocarbons, CFCs

154 Transient tracers, including CFCs, are useful as a water mass tracer because their 155 atmospheric concentration can be uniquely related to a calendar year. In turn, water at the 156 ocean surface records this unique concentration based upon air-water gas partitioning. The 157 equilibrium partitioning between $\mathrm{CFC}$ concentration in the air and water is described by 158 Henry's Law. Dissolved CFCs concentration $C_{\mathrm{w}}\left(\mathrm{mol} \mathrm{kg}^{-1}\right)$ at the locations of interest were 159 obtained from Carbon Hydrographic Data Office (CCHDO). Temperature and salinity data 160 were obtained from the same origin and were used for deriving the Henry's Law Constant $161 H\left(\mathrm{~mol} \mathrm{~kg}^{-1}\right)$. The molar ratio of CFCs in the atmosphere $\chi\left(\mathrm{mol} \mathrm{CFC} \mathrm{mol}{ }^{-1}\right.$ air) were then 162 calculated using

$163 \chi \chi=\frac{C_{w}}{H}$ 
164 The results represented the molar ratio of CFCs in the atmosphere when the water were

165 at the surface. They were compared to recorded atmospheric CFCs concentrations from

166 Carbon Dioxide Information Analysis Center (CDIAC) to determine the calendar year

167 when the water was last contact with the air. ${ }^{10} \mathrm{SF}_{6}$ data were of the highest priority if

168 available; if not, CFC-12 data were used instead.

169

$170 \quad$ RESULTS AND DISCUSSION

171 Truly dissolved surface concentrations of POPs

$172 \quad$ Tropical Atlantic

$173 \sum{ }_{14} \mathrm{PCBs}$ concentrations near the surface of the tropical Atlantic (Cape Verde Abyssal



175 and 180) of $6.2 \mathrm{pg} \mathrm{L}^{-1}$; they constituted $\sim 73 \%$ of all the $\sum{ }_{14} \mathrm{PCBs}$ detected. $\sum{ }_{14} \mathrm{PCBs}$ was

176 close to the high end of reported value of $\left(\sum_{27} \mathrm{PCBs}, 0.24-5.7 \mathrm{pg} \mathrm{L^{-1 }}\right)$ by Gioia et al. ${ }^{11}$ but

177 lower than the measurement ( ${ }_{36} \mathrm{PCBs}$ North Atlantic, $\left.26 \mathrm{pg} \mathrm{L}^{-1}\right)$ by Iwata et al. ${ }^{12}$

$178 \sum$ ICESPCBs was larger than (mean $\left.2.5 \mathrm{pg} \mathrm{L}^{-1}\right)$ by Lohmann et al. ${ }^{13}$ and $\left(0.071-1.7 \mathrm{pg} \mathrm{L}{ }^{-1}\right)$

179 by Gioia et al. ${ }^{11}$

$180 \mathrm{HCB}$ concentration was found at $6.0 \mathrm{pg} \mathrm{L}^{-1}$ near surface, higher than what was found in

181 the North Atlantic (0.1-3 pg L $\left.{ }^{-1}\right)$ by Lohmann et al. ${ }^{13}$ but within the range of Northern

182 Hemisphere average (2-9 pg L $\left.{ }^{-1}\right)$ by Booij et al. ${ }^{14} p, p^{\prime}$-DDT, $o, p^{\prime}$-DDT and $p, p^{\prime}$-DDE were

183 all within the range of 0.2-0.5 $\mathrm{pg} \mathrm{L}^{-1}$, which was in agreement with North Atlantic (0.1-3

$184 \mathrm{pg} \mathrm{\textrm {L } ^ { - 1 }}$ ) by Lohmann et al. ${ }^{13}$ and close to the lower end of Northern Hemisphere average

$185\left(0.3-1.4 \mathrm{pg} \mathrm{L}^{-1}\right)$ by Booij et al. ${ }^{14}$ and detected near $30^{\circ} \mathrm{N}$ Atlantic $\left(0.5 \mathrm{pg} \mathrm{L}^{-1}\right)$ by Iwata et 186 al. $^{12}$ 
187 The only detectable PBDEs were 47, 100 and 99. Concentrations were 1.4, 0.3 and 1.6 $188 \mathrm{pg} \mathrm{L}{ }^{-1}$, slightly higher than $\left(\sim 0.5 \mathrm{pg} \mathrm{L}^{-1}\right.$ for 47 and around $0.1 \mathrm{pg} \mathrm{L}^{-1}$ for 99 and 100) by

189 Lohmann et al. ${ }^{15}$ and (0.02-1.05, nd-0.11 and 0.01-0.53 pg L ${ }^{-1}$ respectively) by Xie et al. ${ }^{16}$

190 Detected $\sum_{7} \mathrm{PAHs}$ was $83 \mathrm{pg} \mathrm{L}^{-1}$ near surface at the tropical Atlantic. This is within the 191 range $\left(\sum_{10}\right.$ PAHs, 58-1070 pg L $\left.{ }^{-1}\right)$ reported by Nizzetto et al. ${ }^{17}$ near the northwest coast of

192 Africa, which was potentially influenced by emerging oil industry, biomass burning and 193 natural source of PAHs in Africa. PAH concentrations measured here were lower than $194\left(\sum_{3}\right.$ PAHs , average of $\left.270 \mathrm{pg} \mathrm{L}^{-1}\right)$ by Lohmann et al. ${ }^{18}$ near the coast of North America. As 195 to individual PAHs, phenanthrene, fluoranthene and pyrene were dominant, which is in 196 agreement with other studies. ${ }^{17,18}$

$198 \quad$ North Atlantic

199 In the North Atlantic (Fram Strait), surface $\sum$ PCBs concentration of the dissolved phase 200 was $0.8 \mathrm{pg} \mathrm{L}^{-1}$ in this study (Figure $3 \&$ Table S12), which was comparable to what was 201 observed for $\sum_{7} \mathrm{PCBs}\left(0.7 \mathrm{pg} \mathrm{L}^{-1}\right)^{4}$ and $\sum_{6} \mathrm{PCBs}\left(<1 \mathrm{pg} \mathrm{L}^{-1}\right)^{19}$. As for individual congeners, 202 the highest concentration was determined by PCB-28, followed by 18, 44, 52 and then 101, 203138,153 . This result is in agreement with result from Gioia et al. ${ }^{19}$ PCB-18, 28, 52, 101, $204118,138,153$ were the most detected congeners in previous studies; they were also the 205 dominant PCBs in this study.

206 HCB was the OCP detected at the highest concentration. The near surface concentration 207 was $10 \mathrm{pg} \mathrm{L}^{-1}$, higher than those reported from the North Atlantic Bloom Experiment $208(\mathrm{NABE})^{20}$ but close to results from the RV Polarstern cruise ARK-XX (high Arctic , 4-10

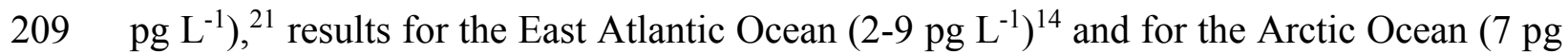


$\left.210 \mathrm{~L}^{-1}\right) .{ }^{22}$ It was mentioned by Lohmann et al. ${ }^{21}$ that $[\mathrm{HCB}]_{\text {diss }}$ was negatively correlated with

211 water temperature $\left(T_{\mathrm{w}}\right):[\mathrm{HCB}]_{\mathrm{diss}}=6.4-0.57 \times T_{\mathrm{w}}$. Considering the higher averaged

212 temperature from the NABE study $\left(10^{\circ} \mathrm{C}\right),[\mathrm{HCB}]_{\text {diss }}$ was close to the other reported values

213 after temperature corrections.

214 There were no HCHs detected, possibly due to the less hydrophobic nature of HCHs

215 which reduced their uptake by PEs. $p, p^{\prime}$-DDE and $p, p^{\prime}$-DDD are two breakdown products

216 of $p, p^{\prime}$-DDT. Their concentrations were around 0.1-0.4 $\mathrm{pg} \mathrm{L}^{-1}$, which were also close to

217 previous studies. ${ }^{20,21} p, p^{\prime}$-DDT concentration was lower than $p, p^{\prime}$-DDE and $p, p^{\prime}$-DDD,

218 indicating that there is no new source of $p, p^{\prime}$-DDT to the central Arctic Basin.

219 The only PBDEs detected were BDE-99 and BDE-100. Surface seawater concentrations

220 in the dissolved phase were $0.4 \mathrm{pg} \mathrm{L}^{-1}$ and $0.025 \mathrm{pg} \mathrm{L}^{-1}$, respectively. Concentrations were

221 similar to those observed in the Asian Arctic by Möller et al. ${ }^{23}$ While BDE-47 was one of

222 the dominant PBDEs in the other studies, it was not detected in Fram Strait (this study).

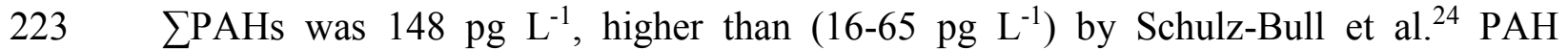

224 compounds detected tend to vary among studies conducted at different regions. Among all

225 the PAHs, fluoranthene was the one more consistently detected. Concentration of

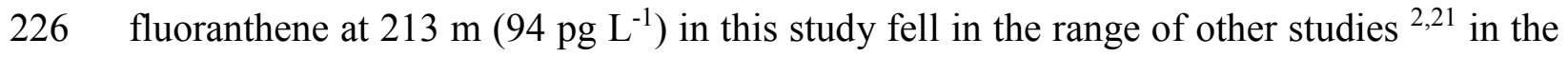

227 same region.

228 In summary, the concentrations of various POPs near the surface of the tropical and 229 northern Atlantic were in agreement with previous measurements reported for the remote 230 Atlantic. Comparisons (sampling year, sampling location, etc) are summarized in Table 231 S13. Overall, the comparison validates the use of PE samplers and the derived 232 concentrations. 
233 A detailed discussion on the certainty of estimated concentrations can be found in the

234 Supporting Information.

235

$236 \quad$ Latitudinal fractionation

237 Next, we investigated whether there are large scale trends in PCB profiles reflecting global

238 processes. As our sampling sites are not directly linked by one major current, any 239 differences in PCB profiles should mainly stem from atmospheric deposition to the surface

240 ocean. As discussed in the methods, linear regression was used to investigate whether there

241 was a trend of the ratio of the compounds detected at the two sites and their physico-

242 chemical properties. Results are given in Figure 2. The overall correlation was not strong

$243\left(\mathrm{R}^{2}=0.25, \mathrm{p}\right.$-value $\left.=0.25\right)$, due to an outlier $(\mathrm{PCB}-28)$. An outlier was defined as a value

244 outside of 1.5 times of interquartile distance (IQD = Q3-Q1) subtracted from or added to

245 the first quartile (Q1) and the third quartile (Q3). ${ }^{25}$ A significant higher concentration of

246 PCB-28 in the north could be resulted from an unknown emission source near the sampling

247 area. After removing PCB-28, the correlation between north-south ratio of POP

248 concentrations and $\log \mathrm{P}_{\mathrm{L}}$ was much improved $\left(\mathrm{R}^{2}=0.95\right)$ and became significant ( $\mathrm{p}$-value

$249=0.001)$. The results imply that higher mobility compounds (higher $\log \mathrm{P}_{\mathrm{L}}$ ) display a

250 relatively greater abundance up north than compounds with lower mobility. This supports

251 the ideas formulated in the cold condensation theory, driven by large-scale atmospheric

252 transport. ${ }^{26}$ Our results agreed with an increasing trend of concentration ratios of PCBs

$253\left(88^{\circ} \mathrm{N}: 62^{\circ} \mathrm{N}\right)$ along with $\log$ vapor pressure observed by Sobek and Gustafsson. ${ }^{27} \mathrm{We}$

254 note, however, that the two samples we used for the comparison were not real surface 255 samples, especially for North Atlantic site. 


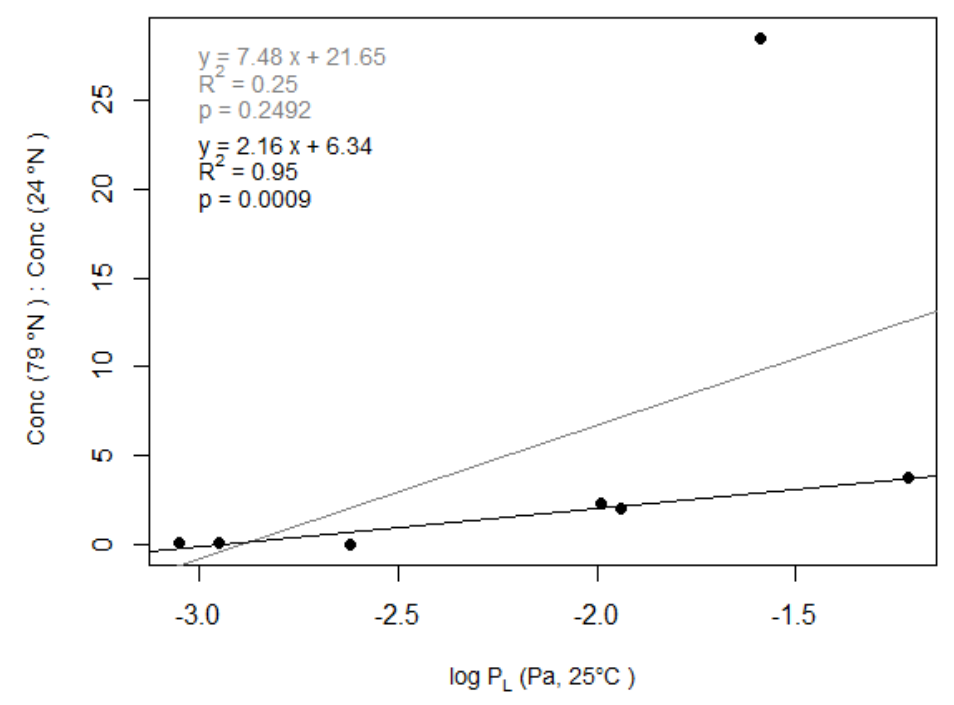

Figure 2. Ratio of the concentration at $79^{\circ} \mathrm{N}$ and $24^{\circ} \mathrm{N}$ for PCBs detected at the depth

258 nearest to the surface at both sites, as a function of log sub-cooled liquid vapor pressure

259 (Pa) at $25^{\circ} \mathrm{C}$ (Table S2). (Grey: all detected PCBs; Black: PCB-28 removed)

261 Depth profile - comparison with the other deep ocean POP measurements

262 Depth profiles were plotted as in Figure 3 (values are given in Table S12). Comparisons 263 were made with the other two studies: Booij et al. ${ }^{2}$ and Schulz-Bull et al ${ }^{24}$. Good agreement 264 was achieved between the three studies. In the tropical Atlantic Ocean, most dissolved 265 PCBs were detected at $\sim 100 \mathrm{fg} / \mathrm{L}$ level with a few major PCBs (e.g. PCB-101,118, 266153,138 ) detected at concentrations larger than 1,000 fg/L, HCB at around 6,000 fg/L and 267 PAHs within 1-200 fg/L. In the North Atlantic Ocean, PCBs were at $\sim 100 \mathrm{fg} / \mathrm{L}, \mathrm{HCB}$ at $268 \sim 10,000 \mathrm{fg} / \mathrm{L}$ in the upper water column and PAHs within 1-100 pg/L (North Atlantic). 269 Details are given in Table S14. 
272 Depth profile shapes

273 PCBs, OCPs and PAHs congeners displayed similar depth profiles; mostly with a

274 maximum at $800 \mathrm{~m}$. Vertical profiles for PBDE are significantly different from the other

275 compounds. All BDEs congeners exhibited a drastic decline in truly dissolved

276 concentrations below $\sim 250 \mathrm{~m}$. Little BDEs were detected at depth, possibly linked to the

277 fact that production of BDEs peaked 20 30 years later than those for PCBs and OCPs.

278 Thus, PCBs and OCPs had more time to penetrate the deeper layers of the oceans, while

279 PBDEs have only touched the surface ocean.

281 Explanations for depth profile

282 No measurements were done above $1400 \mathrm{~m}$ at the Canary Basin site of Booij et al. ${ }^{2}$ and 283 due to the similar concentrations found near the surface at other locations in the Atlantic, 284 the authors concluded that no large concentration gradients existed in the upper $1400 \mathrm{~m}$ at 285 Canary Basin. However, in the present study, a concentration maximum existed at $800 \mathrm{~m}$ 286 which was significantly different from the other depths. We note that neither study was 287 able to fully resolve depth profiles satisfactorily as only a few samplers were deployed, 288 potentially missing important vertical features in POPs concentration. In the present study, 289 sampling depths were restricted to specific coupling points in the mooring line, thus we 290 were not able to add more in addition to the present stations.

291 Two reasons were investigated to explain the shapes of the PCBs, OCPs and PAHs depth 292 profiles: i) Particle binding/sinking; and ii) Water current transport. Chemicals with higher $293 \mathrm{~K}_{\mathrm{ow}}$ (partitioning coefficient between octanol and water) tend to bind to particles more 294 strongly. With particles sinking and getting remineralized in the deep ocean, POPs are 
295 released back into the water. PCBs, for instances, have different levels of chlorination and

296 those with high chlorination degrees have higher tendency to bind to particles. The

297 composition from different PCBs chlorination groups were plotted in Figure S3. There is

298 an increase of di- and tri-PCBs with depth, particularly at $800 \mathrm{~m}$ and below. No trend of

299 increasing contribution from higher chlorinated-PCBs can be seen, suggesting that particle

300 binding/sinking processes did not dominate the $800 \mathrm{~m}$ maximum in PCB concentrations.

301 We note that greatest concentrations of hexa- and hepta-chlorinated congeners were found

302 in the surface samples of the tropical Atlantic, not at depth. Once exported from the surface

303 Ocean, photodegration will not affect PCBs any longer. There is little evidence that

304 biodegradation has affected PCBs, in light of concentrations profiles with depth that are

305 not decreasing. Booij et al. $^{2}$ also pointed out that particle-associated transport is

306 insignificant in transferring contaminants to the deep ocean.

307 The existence of Mediterranean water has been observed in East Atlantic. ${ }^{28}$

308 Mediterranean water sinks and mixes with Eastern Atlantic water after it flows out of the

309 Strait of Gibraltar, reaches equilibrium around $1000 \mathrm{~m}$ in depth and spreads across the

310 North Atlantic. So-called 'Meddies' are anticyclonic rings that were formed after

311 Mediterranean water flows out of the Strait of Gibraltar. They are $100 \mathrm{~km}$ in diameter and

$312800 \mathrm{~m}$ in thickness and could last as long as two or more years. It was estimated that some

$31325 \%$ of the Mediterranean outflow originates in Meddies and this makes Meddies one tool

314 to trace Mediterranean water. ${ }^{29}$ Meddies are normally associated with temperature and

315 salinity anomalies, resulting from the warmer, saltier and younger feature of Mediterranean

316 water. Figure S5 is the vertical section along East Atlantic. There is anomaly at $24.58^{\circ} \mathrm{N}$,

$317800 \mathrm{~m}$ in depth in all vertical profiles in Figure S5. Temperature, salinity and CFC-11 data 
318 indicated a ring of warmer, saltier and younger water mass than surroundings. Although

319 our sampling location was not exactly the same as where the anomaly occurred,

320 considering the size of Meddies and the close proximity of these two locations, intruding

321 from Mediterranean water cannot be ruled out.

322 Another evidence towards the influence of Mediterranean water on the sampler at $800 \mathrm{~m}$

323 in depth is the comparison to reported POPs in the Mediterranean water. From the study

324 conducted in 2006-2007, concentrations in seawater were reported as $\sum{ }_{41} \mathrm{PCBs}_{2-84} \mathrm{pg} \mathrm{L}^{-}$

$325{ }^{1}$ and $\mathrm{HCB}$ up to $1.7 \mathrm{pg} \mathrm{L}^{-1}$ in the Mediterranean Sea and Black Sea. ${ }^{30}$ The importance of

326 penta- and hexa-chlorinated biphenyls were in agreement with tropical Atlantic samples

327 reported here. Reported concentration of HCB in coastal water of Alexandria, Egypt were

328 much higher (surface water: $\left.27 \mathrm{pg} \mathrm{L}^{-1}\right) .{ }^{31}$

329 The implication from our results is that the upper $1800 \mathrm{~m}$ of the water column was not

330 well mixed with respect to POPs concentrations, and there were multiple water layers

331 which potentially had different water mass origins, possibly affecting POPs concentrations

332 and profiles.

333
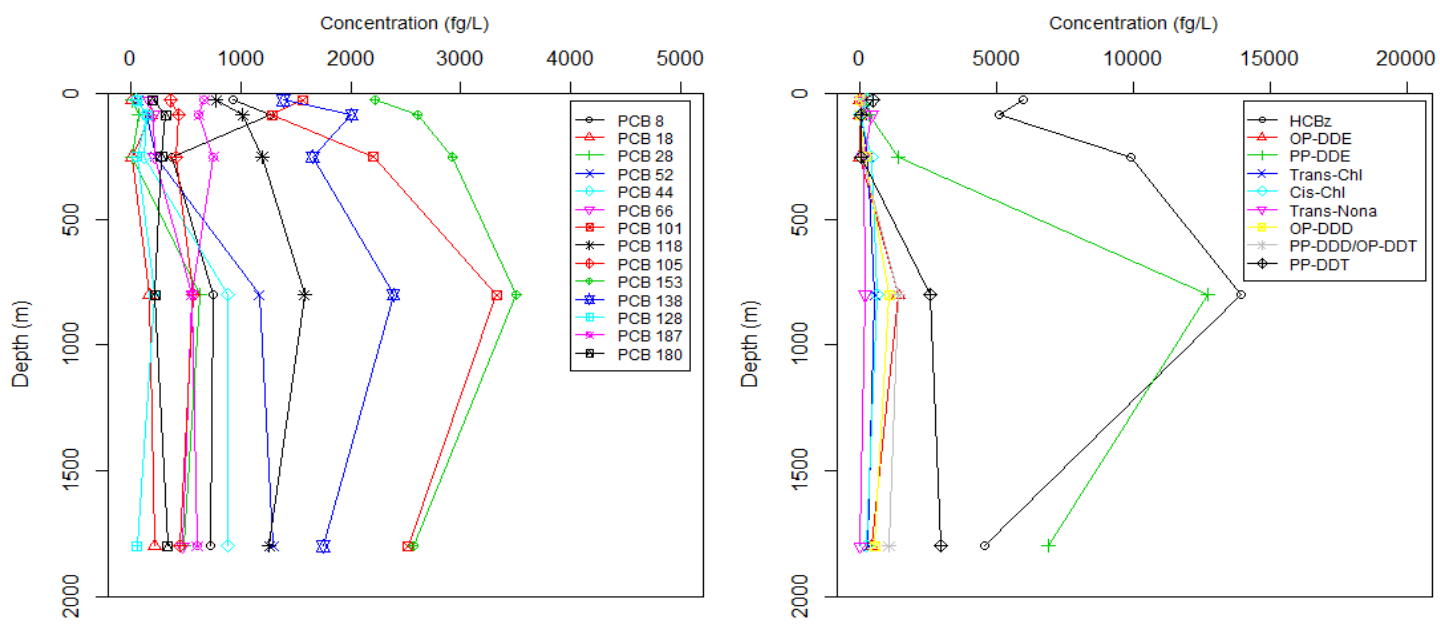
Environmental Science \& Technology

334

335

336

337

338 Depth profile - North Atlantic site

339 Depth Profile Shapes

340 Depth profiles were plotted as in Figure 4 (values are given in Table S12). Most

341 compounds showed similar depth profiles, such as PCBs, HCB and BDE 99. They

342 exhibited a general decrease trend towards the deep and some maximum concentration

343 appearing at $500 \mathrm{~m}$ in depth. Decreasing profiles of $\mathrm{PCBs}^{3,24}$ and $\mathrm{PAHs}^{24}$ were observed in

344 the 1990s in North Atlantic, while a nutrient-like profile was shown recently addressing

345 the importance of advective flow-off from the continental shelf. ${ }^{4}$ The distribution pattern

346 observed in this study neither follows a decreasing nor an increasing trend. Different

347 distribution patterns observed for the other compounds can be partly explained by their

348 separate degradation processes and emission pathways.

349

350

Explanations for depth profile 
351 Similar to the discussion above, particle binding and sinking origination was tested by

352 PCBs chlorination composition plotted in Figure S3. Compared to the results from the

353 tropical Atlantic site, smaller degrees of chlorination tend to yield larger contribution of

354 the $\sum$ PCBs in the North Atlantic, which means the contribution from each group has the

355 order of tri- $>$ tetra- $>$ penta- $>$ hexa- . This composition pattern of chlorinated groups are

356 in line with other studies. ${ }^{4,19}$ No significant fraction of higher chlorinated PCBs was

357 observed along depth, indicating that particle sinking was not a major contributor to the

358 PCBs in depth in North Atlantic either.

359 The Fram Strait is the pathway for water exchange between the North Atlantic and the

360 Arctic Basin. Warm and saline Atlantic water flows into the Arctic Ocean at the eastern

361 side of Fram Strait; cold Arctic water flows out of the Arctic Mediterranean in the western

362 Fram Strait. Different branches of the Norwegian Atlantic Current (NwAC) converge and

363 form the West Spitsbergen Current (WSC). A significant part does not enter the Arctic

364 Ocean, mixes with the outflowing Arctic water and recirculates into the Nordic Seas. ${ }^{32}$ The

365 deep mooring site in this study was influenced by these recirculation water masses. From

3661997 onwards, a deep oceanographic mooring array at $78^{\circ} 50^{\prime} \mathrm{N}^{33}$ as well as three individual

367 moorings at the LTER (Long-Term Ecological Research) observatory HAUSGARTEN ${ }^{34}$

368 were maintained in the Fram Strait. From the mooring data, it was noticed that deep water

$369(\sim 2500 \mathrm{~m}$ deep $)$ in the plateau area near the Fram Strait Sill $\left(\sim 0^{\circ}\right.$ E) reflects mixing

370 properties from two end members: the Greenland Sea Deep Water (GSDW) and the

371 Eurasian Basin Deep Water (EBDW); at mooring site HG-IV (central HAUSGARTEN

372 site), the water near bottom is almost purely EBDW. The mean flow at HG-IV is locally

373 topographically steered but does not achieve the cross sill advection. ${ }^{35}$ Unlike the Tropical 
374 Atlantic sampling site, it is hard to derive the water mass origins for certain depths at the

375 North Atlantic sampling site due to the complexity and vigorousness in the water mixing 376 processes.

377
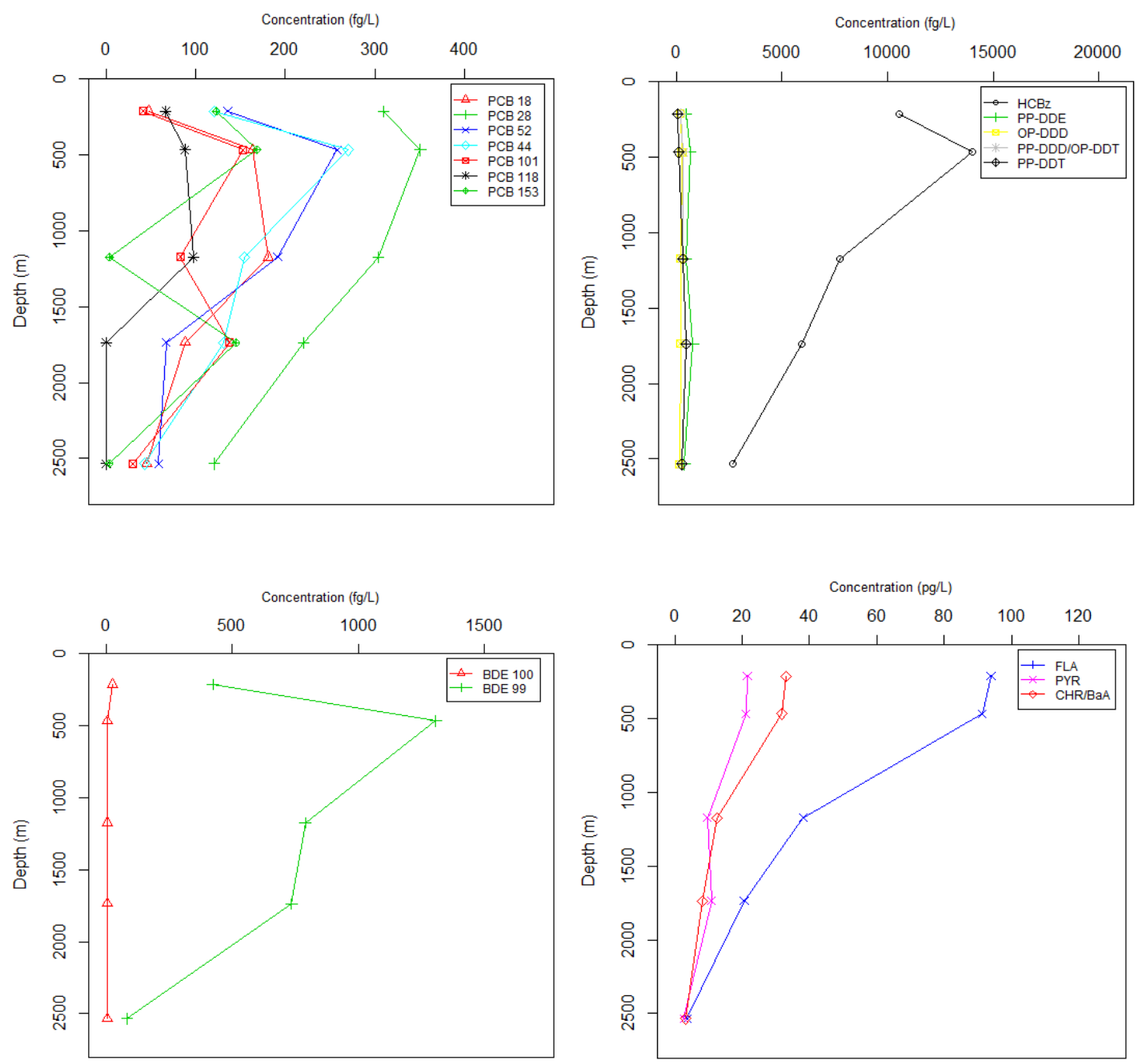

378

379 Figure 4. Depth profiles of POPs (PCBs, OCPs, PBDEs and PAHs) in the North Atlantic.

380 Lines are for connecting points only and do not represent any measurements.

382 CFCs ventilation ages and plots against PCBs profiles

383 Tropical Atlantic 
384 There was no available $\mathrm{SF}_{6}$ data for tropical Atlantic close to our deployment period;

385 CFC-12 data were used instead to assess water mass origin and age. CFC-12 derived

386 ventilation age was plotted against the $\sum$ PCBs in Figure S4. Detailed information for

387 ventilation age calculation was given in Table S15. The three sites chosen from CCHDO

388 for the tropical Atlantic gave close CFC-12 data throughout the water column, indicating

389 little variance of water composition around $\left(24^{\circ} \mathrm{N}, 38^{\circ} \mathrm{E}\right)$. Ventilation age was then derived

390 by averaging out the available ventilation age from SITE1 to SITE 3 (Table S15).

391 The concentration maximum of $\sum \mathrm{PCBs}$ had a ventilation age of around 40 years,

392 coinciding with the peak in PCBs emission in the 1970 s. ${ }^{36}$ However, some other depths

393 that were not sampled may exhibit larger $\sum$ PCBs than $800 \mathrm{~m}$. It is also unknown whether

394 there is a lag in the response time of oceanic POPs to global emission, and how long it

395 might be. As discussed previously, the peak in PCB concentrations at $800 \mathrm{~m}$ could also be

396 due to Mediterranean water masses. Therefore, we conclude here that $\sum$ PCBs detected at

397 the tropical Atlantic site generally followed the emission history of PCBs; yet it is unclear

398 whether the $800 \mathrm{~m}$ maximum reflected the 1970s PCBs emission peak.

$400 \quad$ North Atlantic

$401 \mathrm{SF}_{6}$ data was used for deriving the ventilation age of water masses in the North Atlantic.

402 Large variations occurred between different sites chosen for the $\mathrm{SF}_{6}$ data, most probably

403 resulting from the complexity in bathymetric and water current conditions in this area. The

404 closest sampling $\mathrm{SF}_{6}$ location to our PE sampling site which also covers the whole PE

405 sampling depths was included in Table S15. Figure S4 indicated a maximum in $\sum$ PCBs at 406 a ventilation age of $\sim 10-20$ years, younger than the maximum at tropical Atlantic site. 
407 Again, due to the limited data points, it is hard to accurately determine where the $\sum$ PCBs

408 maximum would occur. The overall distribution pattern of $\sum$ PCBs with ventilation age still

409 followed the global emission pattern, with one peak in the middle and decrease on both

410 sides. The shift in the concentration peak of $\sim 20$ years could be an oceanic POPs response

411 time lag not captured by the tropical Atlantic site measurement.

\section{Mass balance implications for POPs in the Ocean}

414 We selected HCB for calculating mass balance in the Atlantic Ocean because the vertical

415 profiles reported here show no significant difference in absolute concentrations across the

416 Atlantic Ocean and the trend is similar. However, for PCBs, OCPs (other than HCB),

417 PBDEs and PAHs either the concentration or the trend lacks consistency between the two 418 sampling sites.

419 For HCBs, we assumed a uniform spatial distribution across the Atlantic Ocean. Pilson ${ }^{37}$ 420 estimated the whole surface area of Atlantic as $8.65 \times 10^{7} \mathrm{~km}^{2}$ with average depth of 3,700

$421 \mathrm{~m}$. The upper ocean $(0-1,200 \mathrm{~m})$ is loaded with $\mathrm{HCB}$ at a concentration of $9.6 \pm 3.5 \mathrm{pg} \mathrm{L}-1$

422 (mean \pm standard deviation), while the deep ocean $(1,200-3,700 \mathrm{~m})$ has a concentration of $4234.4 \pm 1.6 \mathrm{pg} \mathrm{L}^{-1}$, based on the results of this work. The total amount of HCB residing in the 424 Atlantic Ocean is $1,947 \pm 709 \mathrm{t}$; it accounted for $45 \pm 16 \%$ of the total HCB stored in the 425 ocean if using the estimation from Barber et al $(4,300 \mathrm{t}){ }^{38}$ The total global production of 426 HCB was estimated as $>100,000$ t. ${ }^{39}$ The contemporary environmental burden of HCB was 427 calculated as 10,000-26,000 t. ${ }^{38}$ Hence, the Atlantic Ocean stores less than $2.6 \%$ of HCB 428 ever produced, but contains $4.8-26 \%$ of the global HCB environmental burdens. 


\section{IMPLICATION}

431 The current study confirmed that it is possible to deploy passive samplers to determine

432 vertical POPs gradients in the Oceans. Yet deployment times of around 1 year were

433 insufficient for most POPs to reach equilibrium in 800 and 1,600 um thick sheets. The slow

434 equilibration was in part due to the need to use deployment cages to guarantee safe

435 deployment and retrieval of passive samplers. We were able to constrain sampling rates by

436 combining results from different thicknesses, PRC-laden sheets and modeling. Future

437 deployments would benefit from more PRC-impregnated samplers to derive in situ 438 sampling rates.

439 Results from this study supported previous work in highlighting the important role of 440 deep ocean as a compartment storing POPs. The presence of numerous POPs in deeper 441 water suggests that the deep ocean carries a significant mass already, particularly of the 442 legacy POPs. An intriguing observation from the two sites considered here is that lateral 443 water mass transport might be more important than vertical POP transport on settling 444 particles. As an example, PBDEs had penetrated the deep water masses of the Atlantic 445 Ocean to a much smaller degree than the legacy PCBs and OCPs. Clearly, additional work, 446 ideally both at numerous sites and with greater vertical resolution could help constrain the 447 importance of water mass versus particle-bound transport of POPs to depth.

449 ASSOCIATED CONTENT

450 Supporting Information 
451 Additional details related to the physicochemical constants, sampling setup,

452 instrumental analysis, quality control and CFC information are available. This material is 453 available free of charge via the Internet at http://pubs.acs.org.

455 AUTHOR INFORMATION

456 Corresponding Author

457 *E-mail: lohmann@gso.uri.edu; Tel 401-874-6612; fax 401-874-6811

\section{Author Contributions}

459 The manuscript was written through contributions of all authors. All authors have given

460 approval to the final version of the manuscript.

$461 \quad$ Notes

462 The authors declare no competing financial interest.

463

464 ACKNOWLEDGMENTS

465 We acknowledge funding from the National Science Foundation (ARC 1203486) to

466 study the transport of POPs into the Arctic Ocean. We thank J. Thomas Farrar (WHOI) for

467 sampler deployment and current data at the tropical Atlantic site, Brice Loose (URI) for

468 assistance with CFC data, and the ship's crew and of Normen Lochthofen for the

469 deployment and recovery of the mooring in Fram Strait during R/V Polarstern cruise ARK-

$470 \mathrm{XXVII} / 2$. This is publication e39092 of the Alfred-Wegener-Institut Helmholtz-Zentrum

471 für Polar- und Meeresforschung, Germany. 
REFERENCES

475

476

477

478

479

480

481

482

483

484

485

486

487

488

489

490

491

492

493

494

495

496

497

498

499

500

501

502

503

504

505

506

(1) Gioia, R.; Dachs, J.; Nizzetto, L.; Lohmann, R.; Jones, K. C. Atmospheric Transport, Cycling and Dynamics of Polychlorinated Biphenyls ( PCBs ) from Source Regions to Remote Oceanic Areas. In Occurrence, Fate and Impact of Atmospheric Poluutants on Environmental and Human Health, ACS Symposium Series; L. McConnell, J. Dachs, C. J. H., Ed.; 2013; Vol. 1149 (ISBN13: 9780841228900, eISBN: 9780841228917), pp 3-18.

(2) Booij, K.; Bommel, R. Van; Aken, H. M. Van; Haren, H. Van; Brummer, G. A.; Ridderinkhof, H. Passive sampling of nonpolar contaminants at three deep-ocean sites. Environ. Pollut. 2014, 195, 101-108.

(3) Schulz, D. E.; Petrick, G.; Duinker, J. C. Chlorinated biphenyls in North Atlantic surface and deep water. Mar. Pollut. Bull. 1988, 19 (10), 526-531.

(4) Sobek, A.; Gustafsson, Ö. Deep water masses and sediments are main compartments for polychlorinated biphenyls in the Arctic Ocean. Environ. Sci. Technol. 2014, 48 (12), 6719-6725.

(5) Lohmann, R. A critical review of low-density polyethylene's partitioning and diffusion coefficients for trace organic contaminants and implications for its use as a passive sampler. Environ. Sci. Technol. 2012, 46, 606-618.

(6) Lohmann, R.; Muir, D. Global aquatic passive sampling (AQUA-GAPS): Using passive samplers to monitor POPs in the waters of the world. Environ. Sci. Technol. 2010, 44 (3), 860-864.

(7) Bartkow, M. E.; Hawker, D. W.; Kennedy, K. E.; Müller, J. F. Characterizing Uptake Kinetics of PAHs from the Air Using Polyethylene-Based Passive Air Samplers of Multiple Surface Area-to-Volume Ratios. Environ. Sci. Technol. 2004, 38 (9), 2701-2706.

(8) Booij, K.; Smedes, F.; Van Weerlee, E. M. Spiking of performance reference compounds in low density polyethylene and silicone passive water samplers. Chemosphere 2002, 46, 1157-1161.

(9) Booij, K.; Smedes, F. An improved method for estimating in situ sampling rates of nonpolar passive samplers. Environ. Sci. Technol. 2010, 44 (17), 6789-6794.

(10) Bullister, J. Atmospheric CFC-11, CFC-12, CFC-113, CCl4 and SF 6 Histories (1910-2014) http://cdiac.ornl.gov/oceans/new_atmCFC.html (accessed Jun 10, 2015). 
507

508

509

510

511

512

513

514

515

516

517

518

519

520

521

522

523

524

525

526

527

528

529

530

531

532

533

534

535

536

537

538

539

540

(11) Gioia, R.; Nizzetto, L.; Lohmann, R.; Dachs, J.; Temme, C.; Jones, K. C. Polychlorinated Biphenyls (PCBs) in Air and Seawater of the Atlantic Ocean: Sources, Trends and Processes. Environ. Sci. Technol. 2008, 42 (5), 1416-1422.

(12) Iwata, H.; Tanabe, S.; Sakai, N.; Tatsukawa, R. Distribution of Persistent Organochlorines in the Oceanic Air and Surface Seawater and the Role of Ocean on Their Global Transport and Fate. Environ. Sci. Technol. 1993, 27 (6), 10801098.

(13) Lohmann, R.; Klanova, J.; Kukucka, P.; Yonis, S.; Bollinger, K. PCBs and OCPs on a east-to-west transect: The importance of major currents and net volatilization for PCBs in the atlantic ocean. Environ. Sci. Technol. 2012, 46, 10471-10479.

(14) Booij, K., van Bommel, R., Jones, K.C., Barber, J. L. Air-water distribution of hexachlorobenzene and 4,40-DDE along a North-South Atlantic transect. Mar. Pollut. Bull. 2007, 54 (6), 814-819.

(15) Lohmann, R.; Klanova, J.; Kukucka, P.; Yonis, S.; Bollinger, K. Concentrations, fluxes, and residence time of PBDEs across the tropical Atlantic Ocean. Environ. Sci. Technol. 2013, 47, 13967-13975.

(16) Xie, Z.; Möller, A.; Ahrens, L.; Sturm, R.; Ebinghaus, R. Brominated flame retardants in seawater and atmosphere of the Atlantic and the southern ocean. Environ. Sci. Technol. 2011, 45 (5), 1820-1826.

(17) Nizzetto, L.; Lohmann, R.; Gioia, R.; Jahnke, A.; Temme, C.; Dachs, J.; Herckes, P.; Guardo, A. Di; Jones, K. C. PAHs in Air and Seawater along a North-South Atlantic Transect: Trends, Processes and Possible Sources. Environ. Sci. Technol. 2008, 42 (5), 1580-1585.

(18) Lohmann, R.; Klanova, J.; Pribylova, P.; Liskova, H.; Yonis, S.; Bollinger, K. PAHs on a west-to-east transect across the tropical Atlantic Ocean. Environ. Sci. Technol. 2013, 47 (6), 2570-2578.

(19) Gioia, R.; Lohmann, R.; Dachs, J.; Temme, C.; Lakaschus, S.; Schulz-Bull, D.; Hand, I.; Jones, K. C. Polychlorinated biphenyls in air and water of the North Atlantic and Arctic Ocean. J. Geophys. Res. 2008, 113 (D19), D19302.

(20) Zhang, L.; Bidleman, T.; Perry, M. J.; Lohmann, R. Fate of chiral and achiral organochlorine pesticides in the north Atlantic bloom experiment. Environ. Sci. Technol. 2012, 46, 8106-8114.

(21) Lohmann, R.; Gioia, R.; Jones, K. C.; Nizzetto, L.; Temme, C.; Xie, Z.; SchulzBull, D.; Hand, I.; Morgan, E.; Jantunen, L. Organochlorine pesticides and PAHs 
in the surface water and atmosphere of the North Atlantic and Arctic Ocean. Environ. Sci. Technol. 2009, 43 (15), 5633-5639.

(22) Strachan WMJ, Fisk A, Teixeira CF, Burnsiton DA, N. R. PCBs and organochlorine pesticide concentrations in the waters of the Canadian Archipelago and other Arctic regions (Abstract 13). In Proceedings of the Workshop on persistent organic pollutants (POPs) in the Arctic: Human health and environmental concerns.; AMAP report: Arctic Monitoring and Assessment Program: Rovaniemi Finland, 2000.

(23) Möller, A.; Xie, Z.; Cai, M.; Zhong, G.; Huang, P.; Cai, M.; Sturm, R.; He, J.; Ebinghaus, R. Polybrominated diphenyl ethers vs alternate brominated flame retardants and dechloranes from East Asia to the arctic. Environ. Sci. Technol. 2011, 45 (16), 6793-6799.

(24) Schulz-Bull, D. E.; Petrick, G.; Bruhn, R.; Duinker, J. C. Chlorobiphenyls (PCB) and PAHs in water masses of the northern North Atlantic. Mar. Chem. 1998, 61 (1-2), 101-114.

(25) Tukey, J. W. Exploratory data analysis.; Addison-Wesley, 1977.

(26) Wania, F.; Mackay, D. Peer reviewed: tracking the distribution of persistent organic pollutants. Environ. Sci. Technol. 1996, 30, 390A - 6A.

(27) Sobek, A.; Gustafsson, O. Latitudinal fractionation of polychlorinated biphenyls in surface seawater along a 62 degrees N-89 degrees $\mathrm{N}$ transect from the southern Norwegian Sea to the North Pole area. Environ. Sci. Technol. 2004, 38 (10), 27462751.

(28) Martí, S.; Bayona, J. M.; Albaigés, J. A Potential Source of Organic Pollutants into the Northeastern Atlantic: The Outflow of the Mediterranean Deep-Lying Waters through the Gibraltar Strait. Environ. Sci. Technol. 2001, 35 (13), 2682-2689.

(29) Knauss, J. A. Introduction to physical oceanography, 2nd ed.; Waveland Press, Inc., 2005.

(30) Berrojalbiz, N.; Dachs, J.; Del Vento, S.; Ojeda, M. J.; Valle, M. C.; CastroJiménez, J.; Mariani, G.; Wollgast, J.; Hanke, G. Persistent organic pollutants in mediterranean seawater and processes affecting their accumulation in plankton. Environ. Sci. Technol. 2011, 45 (10), 4315-4322.

(31) Abd-Allah, A. M. A. Organochlorine contaminants in microlayer and subsurface water of Alexandria Coast, Egypt. J AOAC Int 1999, 82, 391-398. 
574

575

576

577

578

579

580

581

582

583

584

585

586

587

588

589

590

591

592

593

594

595

596

597

598

599
(32) Schauer, U.; Fahrbach, E.; Osterhus, S.; Rohardt, G. Arctic warming through the Fram Strait: Oceanic heat transport from 3 years of measurements. J. Geophys. Res. 2004, 109 (6), 1-14.

(33) A. Beszczynska-Möller, E. Fahrbach, U. Schauer, E. H. Variability in Atlantic water temperature and transport at the entrance to the Arctic Ocean 1997-2010. ICES J. Mar. Sci. 2012, 69, 852-863.

(34) Soltwedel, T.; Bauerfeind, E.; Bergmann, M.; Bracher, A.; Budaeva, N.; Busch, K.; Cherkasheva, A.; Fahl, K.; Grzelak, K.; Hasemann, C.; et al. Natural variability or anthropogenically-induced variation? Insights from 15 years of multidisciplinary observations at the Arctic open-ocean LTER site HAUSGARTEN. Ecol. Indic. 2016, 65, 89-102.

(35) Appen, W.-J. Von; Schauer, U.; Cabrillo, R. S.; Bauerfeind, E.; BeszczynskaMöller, A. Exchange of warming deep waters across Fram Strait. Deep Sea Res. Part I 2015, 103, 86-100.

(36) Jones, K. C.; Barber, J. L.; Booij, K.; Jaward, F. M. Evidence for dynamic airwater coupling of persistent organic pollutants over the open Atlantic Ocean. Environ. Sci. Technol. 2004, 38, 2617-2625.

(37) E.Q.Pilson, M. An introduction to the chemistry of the sea, 2nd ed.; Cambridge University Press, 2013.

(38) Barber, J. L.; Sweetman, A. J.; Van Wijk, D.; Jones, K. C. Hexachlorobenzene in the global environment: Emissions, levels, distribution, trends and processes. Sci. Total Environ. 2005, 349 (1-3), 1-44.

(39) ATSDR. Toxicological profile for HCB. US Department of Health and Human Services, Public Health Service, Agency for Toxic Substances and Disease Registry (ATSDR); Atlanta, GA, 1997. 


\section{TOC Art}
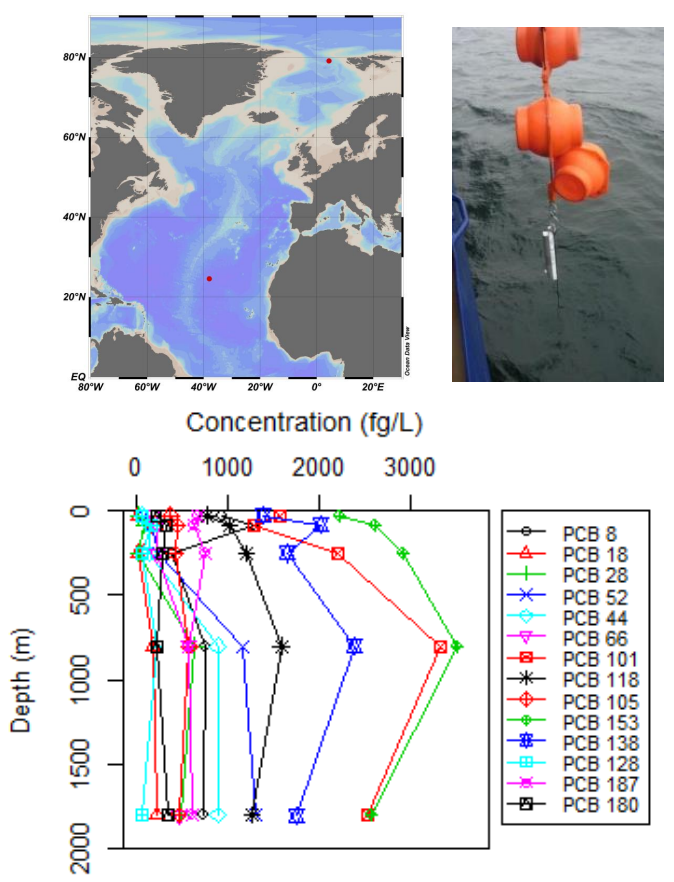